\title{
Una interpretación teórico-cultural de la ciudad de Sevilla. Reseña de Schwab (2013) Texturas de una ciudad*
}

\section{A cultural-studies interpretation of Seville. Review of Schwab (2013) Textures of a City}

\author{
Pascual Riesco Chueca** \\ Fecha de recepción: 02-12-2015 - Fecha de aceptación: 10-12-2015 \\ Hábitat y Sociedad (ISSN 2173-125X), n. ${ }^{\circ}$ 9, noviembre de 2016, pp. 203-208.
}

\begin{abstract}
Summary
A city's cultural profile is made up of a peculiar assortment of the dominant images and discourses brought forward in its presentation to the world. Schwab's book focuses on the origins of Seville's cultural capital, as well as the processes whereby themes and contents are selected and reproduced. In what ways are codes and values stabilized and transmitted; who were the intervening actors, at what times and with which aims, responsible for setting up the city's imagery and keeping it alive under deep transformations of the production model: such are the core research topics of this book, which brings out the complexity of the dialogue / coproduction process sustained by natives and visitors in the making of the urban image.
\end{abstract}

\section{Key words}

Cultural Studies, Seville, City Image, Collective Identity, Symbolic Reproduction

\begin{abstract}
Resumen
La singularidad de una ciudad se despliega a través de la peculiar composición de los discursos e imágenes dominantes en su presentación al mundo. Schwab dirige en su libro una mirada atenta a los orígenes del capital cultural sevillano, y a los procesos de selección y reproducción de temas. De qué modo se consolidan y transmiten códigos y valores; qué actores han intervenido, con qué intereses y en qué momentos, para establecer el imaginario de la ciudad, y para someterlo a sucesivas adaptaciones ante los cambios del modelo productivo: tales son los ejes de esta indagación, que hace aflorar la complejidad del diálogo o coproducción que nativos y foráneos han mantenido para la estilización de la imagen de la ciudad.
\end{abstract}

\section{Palabras clave}

Teoría Cultural, Sevilla, Imagen Urbana, Identidad Colectiva, Reproducción Simbólica
Christiane Schwab: Texturen einer Stadt. Kulturwissenschaftliche Lektüren von Sevilla. [Texturas de una ciudad. Lecturas sevillanas desde los Estudios Culturales]. Fráncfort del Meno / Nueva York: Campus Verlag [ISBN 978-3-593-39905-8], 2013, 390 pp.

** Universidad de Sevilla, Departamento de Ingeniería Aeroespacial. Correo: riescochueca@us.es.
La corriente teórica denominada Estudios Culturales (Cultural Studies) aspira a modelar lo sociopolítico a través de una comprensión abstracta y multidisciplinar de lo cultural. Se explora el modo en que las prácticas de una sociedad y sus significados y discursos dominantes entran en circuitos de refuerzo mutuo. A la hora, sin embargo, de dirigir la atención hacia un objeto tan rico e inabarcable como una ciudad, y más en el caso de la ensimismada y densa en historia Sevilla, las dificultades del análisis se hacen manifiestas. ¿Cómo ofrecer pautas globales —una fórmula cultural para Sevilla- que expliquen la singularidad de la ciudad sin incurrir en reduccionismo ni esencialismo? Las prácticas sociales distintivas de los sevillanos, la bolsa de significados e imágenes compartidos, los valores asignados a fechas y lugares; las condiciones sociales y económicas que consolidan y reproducen tales significados, imágenes y valores: todo ello compone sin duda un sistema, pero el esfuerzo de comprender la lógica interna de este puede hipnotizar al estudioso que, en su afán de buscar claves, puede desatender matices importantes y exagerar artificialmente la naturaleza encapsulada de su objeto de estudio. 
La visión ofrecida por el libro, por otra parte, es una mirada desde fuera y lejos, sin el tibio calor de la familiaridad o la toma previa de partido, apasionada o desdeñosa, que han acompañado a tantas crónicas de viajeros y tantos libros laudatorios de elaboración autóctona. En esta operación de análisis global y distanciado (aunque asistida por un escrupuloso trabajo de campo en el caso de este libro), los riesgos son tan patentes como los posibles triunfos. Se dispone de la frescura de una contemplación despojada de complacencias y rutinas cognitivas, es cierto; pero cabe incurrir en algún desliz, por simple desconocimiento de detalles y conexiones importantes: es otra vía por la que pueden escaparse matices y paradojas significativas.

Dos riesgos destacados, en definitiva: que la voluntad de entender el cuadro oscurezca porciones destacadas del conjunto; y que la distancia enfríe la mirada por ausencia de ese manto cordial de estímulos que teje la cercanía del sujeto a su tema. Y, al mismo tiempo, dos bazas intelectualmente atrayentes: la capacidad de percibir en modo abstracto el conjunto de manifestaciones coloridas y pintorescas que abigarran el cartel de una vieja ciudad como Sevilla; y la de superar crónicas y panegíricos desgastados por el uso.

El libro de Christiane Schwab es un vigoroso pulso intelectual con la ciudad de Sevilla, que sortea con eficacia las dificultades inherentes a la ambición del estudio. Por él desfilan materiales de muy diversa procedencia disciplinar - históricos, urbanísticos, etnográficos, literarios, artísticos, sociopolíticos- para sedimentar en unas líneas de interpretación contundentes y sumarias. Las fuentes de que se nutren estas lecturas sevillanas son refrescantemente polimorfas. A una vigorosa artillería científica, que abre puertas allende la lengua inglesa incorporando a autores del ámbito alemán, poco frecuentados por la erudición española, se unen recortes de prensa, evocaciones de viajeros, pregones, folletos y programas, libros locales de consumo, catálogos de exposición, entrevistas con figuras de la ciudad y otros elementos del paisaje semiótico (carteles, anuncios, escaparates). La pluralidad de recursos movilizada en el libro ofrece un mirador privilegiado tanto hacia la Sevilla histórica como hacia la nueva economía de la ciudad, crecientemente volcada al turismo y la industria cultural. Integrar esta diversidad elevándola a un patrón consistente será una de las arriesgadas incitaciones del recorrido.

La dificultad se redobla en el caso de Sevilla, cuyos códigos han sido endurecidos por innumerables propagandistas y protocolarios ( $l o-$ cal boosters y formulaic journalists en la terminología de Suttles, 1984), celosos de exaltar y fijar sus esencias. Sevilla, ciudad mitogénica, cuna de Don Juan, Carmen y Fígaro, es un retablo donde la mirada de los primeros viajeros románticos imprime con su cuño formas indelebles (González Troyano, 2007). La representación ajena, por medio de la cual la fantasía del viajero dibujaba imágenes pintorescas combinando arabofilia, medievalismo y ensimismamiento, es un juguete de percepción y un copioso capital cultural que los propios sevillanos gustan de administrar a su manera. La autora sigue a Pérez-Bustamante (1992) en la descripción de una circularidad dinámica entre exotismo (pulsiones de definición y estilización cultural ejercidas por los de fuera) y casticismo (estereotipos cocinados para su uso interno por los sevillanos).

Es cierto que eran múltiples los avales con los que contaba la ciudad para cautivar a los primeros viajeros. La gran extensión de su tejido urbano, limpiamente engastado en su enorme recinto amurallado, parecía fijar casi sin asistencia de hechos orográficos una voluntad de ensi- 
mismamiento, una obsesión urbana en la que resultaba fácil adivinar una potente voluntad de ser. El trazado callejero laberíntico proponía lecturas mágicas, de misterio y hallazgo, prestigiando iniciáticamente al conocedor. El río, al enarenarse, desconectaba a la ciudad de su horizonte americano, dejándola ensimismada en sus claustros y jardines, entre palacios evocadores de la desmesurada empresa de Indias. La ubicación de la ciudad en una de las últimas estaciones previas al salto africano garantizaba en el viajero un crescendo de expectación: el mismo que hace a Goethe dedicar atención creciente en su Viaje a Italia a los jalones finales del recorrido, ya en Nápoles y en Sicilia. El choque entre un catolicismo frondoso y ritual y los ecos de un pasado musulmán, artificiosamente modulados, constituían un recurso expresivo inagotable. Con todos estos ingredientes, la imaginación romántica fabricó un inflamado bastidor para uso de viajeros y turistas: se construye así el paradójico provincianismo de Sevilla, un provincianismo universalizado que no defiende su singularidad blindándose contra lo foráneo, sino intentando desplegar sus seducciones para absorber y metabolizar con peculiar estilo lo que viene de fuera.

Sostiene Schwab que Sevilla ha reproducido infatigablemente y por distintas vías este imaginario, de raíz romántica, estratégicamente adaptado y modulado por los nativos, un imaginario del que se nutren tanto folcloristas — quienes ensalzan el brillo externo de esta tradición- como puristas - los que aspiran a saborear esencias más íntimas, recreándose, en la voz de Cernuda, "con un tesoro intacto que no profana el mundo"- . Ni los grandes cambios contemporáneos ni la emergencia de iniciativas de renovación han sido capaces de desmontar el edificio mítico de la ciudad, pues los discrepantes que expugnan los valores del conservadurismo y el ombliguismo sevillano remiten en su oposición a los mismos valores fundacionales. Incluso los grandes creadores del 27, según la autora, si bien alumbraron con nuevos recursos estilísticos una prodigiosa radicalidad de sentimiento y arte, siguieron siendo fieles a un repertorio de temas ya trazados por los mitificadores románticos.

Para explicar la prolongada vigencia de los mitos de la ciudad, el estudio invoca diversos factores de estabilización. Sevilla ha tenido un pasado orientado al campo: la oligarquía local era poseedora de tierras, y sus valores eran los de labradores a distancia, con un ritmo ceñido a la repetición de las estaciones: los acontecimientos principales del calendario sevillano —Semana Santa, Feria, Rocío—, en su predecible retorno, consolidan una interpretación del tiempo cíclica, inmutable, esencialmente conservadora. Los elementos celebrados en estas fiestas son ajenos al nervioso pulso de una vida industrial: el catolicismo popular en la Semana Santa, el respetuoso orden social en la Feria, el vínculo ritual con el campo en el Rocío. Otros grupos sociales han minado gradualmente la hegemonía de aristócratas y latifundistas, pero han preservado sus valores; el franquismo ensalzó la alegría sevillana como contrapunto desenfadado a la crispación obrera: la católica y mariana, castiza y barroca, risueña y liviana Sevilla; la tauromaquia, el flamenco, la ópera vivifican y destilan un repertorio de temas que reiteran los mitos sevillanos; la capitalidad de la autonomía andaluza, lejos de debilitar el esquema heredado, lo consagró como pauta legitimadora; la transición a una economía de servicios y la especialización turística favorecieron el reciclaje de los viejos iconos y narrativas para nuevos fines de identidad urbana en contexto de competencia internacional.

Sevilla es también un lugar multigeneracional (Generationenort), don- 
de los recuerdos se heredan y lo autobiográfico se enriquece con narrativas transmitidas de padres a hijos. Es un entorno de densa memoria (temporally rich en la terminología de Urry, 2005), cuyos residentes imaginan revivir añejos recorridos y acudir a viejas citas, compartiendo prácticas espaciales y temporales con una espiral de generaciones anteriores. Los procesos de transformación urbana son experimentados en mezcolanza dolorosa e inseparable del propio envejecer, de manera que la biografía personal entra en resonancia con el devenir urbano. Borges formula, en sus mitificaciones bonaerenses, este íntimo entrelazarse de ciudad y vida: "Y la ciudad, ahora, es como un plano / de mis humillaciones y fracasos; / desde esa puerta he visto los ocasos / y ante ese mármol he aguardado en vano". La tradicional resistencia de los sevillanos a trasladarse a otra parte y la supervivencia de lazos familiares de compleja ramificación refuerzan este vínculo, trasegando y concentrando sin cesar memorias.

Desde el punto de vista espacial, el apiñamiento del caserío es metáfora de una cohesión obstinadamente defensiva, que no ceja en su empeño de dorar año tras año las piezas de su capital simbólico. El crecimiento urbano durante el último siglo, con su amorfo desbordamiento de límites, no cuestiona la hegemonía del casco antiguo, revalidada cada año con el rito procesional, que religa barriadas lejanas con el viejo núcleo urbano y establece un clímax de centralidad a través de expresiones como "carrera oficial", "pedir la venia", "paso por la Campana”. Al mismo tiempo, tanto el exorno de pasos y templos, como los interiores de caseta en la Feria, o las carretas y simpecados en el Rocío, consolidan una estética historicista, de raíz barroca, que materializan los vínculos de la ciudad con una visión florida e idealizada de su propio pasado. Los elementos de este decorado son asumidos voluntariamente por los dueños de bares, tablados, oficinas, talleres y restaurantes, que insertan imágenes de la Pasión y escenas taurinas en sus fondos cotidianos. La restauración de iglesias, palacios, conventos actualiza el legado monumental, que es, con arreglo a una muy apropiada cita de Lowenthal (1985, p. 389), "el principal catalizador de la identidad colectiva de base histórica”.

La autora presta especial atención al decorado sevillano, la estética exterior, tal vez en detrimento de otras líneas de interpretación que quedan sin embargo insinuadas en el texto: los deleites interactivos que completan la materialidad del espacio con expectativas y vuelos de la imaginación. El jardín sevillano ha sido concebido como la esencia secreta de la ciudad, materia de ensoñaciones poéticas desde antes del Renacimiento (Cortines Torres, 2000). Un puro placer espacial, de interiores y saltos de luz, que siembra en la mente del paseante vislumbres de patios exquisitos y ecos de fuentes cantoras: recintos de intimidad que exaltaba Antonio Machado - "Dadme una Sevilla vieja / donde se dormía el tiempo, / con palacios, con jardines, / bajo un azul de convento"-. O la opción paisajística, que propone relaciones sensoriales con el todo de la ciudad, en el caso de Sevilla más corporales que visuales para el paseante embebido en su angosto laberinto (López Lloret, 2003).

La argumentación desplegada en el libro, guiada con tenaz lucidez y bien administrado método, podría ganar en elocuencia si se hubiera aplicado en dosis mayor el comparativismo con otras ciudades europeas. Si bien es evidente en el caso de Sevilla que los estereotipos iniciados por visitantes y consolidados por nativos terminan por labrar una cárcel dorada para la ciudad, puede también pensarse que la misma presión conservadora ejercida por la mitografía urbana se registra, 
aunque en menor grado, en otras ciudades. La literatura y las artes, una vez acuñadas como moneda corriente para el consumo cultural, adquieren un carácter inherentemente despolitizado e intemporal. Los mitos de gran circulación privilegian el capricho de los protagonistas o los sumen en el fatalismo: en cualquiera de los casos, oscurecen los hilos de la motivación socio-política. A la figura del pícaro, del fresco buscavidas sevillano, domesticada por las artes de la pintura y la literatura, podría contraponerse la de otros accesorios literarios no menos universales: los gamins de París, los ragazzi de Roma, fraguados con intención política por creadores como Hugo o Pasolini, pero despolitizados después al circular por las vías de la gran difusión cultural. Podría ser de interés, en el caso de Sevilla, confrontar la figura folclórica del pícaro, cuya significación es estetizada y asimilada por el canon de la sevillanía, con una contrafigura de reciente aparición, la del cani: pieza inquietante del paisaje social, sin rasgos de color local, con una marginalidad opaca y deslocalizada, refractaria a la inclusión en los circuitos simbólicos de la ciudad.

Un aspecto apenas tratado por el libro es sin embargo de honda significación para la autoimagen de los sevillanos y teje un sutil filtro de reconocimiento y de privacidad de grupo ante la mirada foránea: el humor. La suave guasa de la ciudad dispone un tejido impalpable que lubrica los intercambios y fricciones del trato cotidiano, al tiempo que establece una secreta connivencia mediante contraseñas de humor, a menudo desapercibidas, pero contundentes en su configuración de una línea demarcadora entre la vida interior de los sevillanos (nativos y asimilados) y los visitantes de fuera. Puede tal vez pensarse que la ciudad, al adoptar moldes externos para configurar su canon, se reserva esta cláusula de soterrada indocilidad, esta burlona deconstrucción que relativiza jerarquías y monopolios culturales.

Podría también proponerse una indagación, con el mismo modelo teórico que sustenta el libro, acerca de los riesgos del vaciamiento de todo el edificio simbólico sevillano, por abuso del recetario fácil y la estilización superficial exigidos por la cultura de masas. El fachadismo, que socava calles enteras, reduciéndolas a un decorado de banal fisonomía historicista; el adelgazamiento de las fuentes de inspiración del flamenco y la canción; la acelerada conversión en parque temático del Barrio de Santa Cruz; la transformación de Feria, Semana Santa y Rocío, fiestas infiltradas por nuevas formas de celebración planas y desestructuradas, como el botellón o los megaconciertos: ¿son elementos que podrían minar desde dentro las bases del capital cultural de la ciudad?; ¿o, por el contrario, estas presiones son parte de una dinámica que afila y templa los perfiles de una nueva mitografía? Un planteamiento de base cultural no puede por sí solo dar respuesta a estas y otras preguntas, lo que invita a exploraciones complementarias desde disciplinas complementarias.

La inmersión en estas lecturas sevillanas es en todo caso una experiencia rica en estímulos y placentera en su bien dirigida secuencia. Ha de agradecerse la atenta y reflexiva dedicación de la autora, que hace aflorar intuiciones y construye teoría sobre un torso conceptual robusto. Despertaría mucho interés en la ciudad una edición traducida de este ambicioso texto. El infatigable acopio de materiales, las innumerables y bien traídas referencias bibliográficas, el aprovechamiento de aportaciones de muy diversa procedencia definen un marco de contemplación renovador, que enriquece y ordena con una nueva voz el campo de los estudios sobre teoría urbana en general y sobre Sevilla en particular. 


\section{Referencias}

Cortines Torres, J. (2000). Jardines de Sevilla en la lírica castellana. Boletín de la Real Academia Sevillana de Buenas Letras: Minervae Baeticae, 28, 93-123.

González Troyano, A. (2007). Don Juan, Fígaro y Carmen. Sevilla: Fundación José Manuel Lara.

López Lloret, J. (2003). La ciudad construida. Historia, estructura y percepción en el conjunto histórico de Sevilla. Sevilla: Diputación de Sevilla.

Lowenthal, D. (1985). The Past is a Foreign Country. Cambridge: Cambridge University Press.
Pérez-Bustamante Mourier, A. S. (1992). Cultura popular, cultura intelectual y casticismo. En Pérez-Bustamante, A. S. y Romero Ferrer, A. (eds.), Casticismo y literatura en España. Cádiz: Universidad de Cádiz, pp. 125-162.

Suttles, G. D. (1984). The cumulative texture of local urban texture. American Journal of Sociology, 90 (2), 283-304.

RIESCO CHUECA, Pascual. Una interpretación teórico-cultural de la ciudad de Sevilla. Reseña de Schwab (2013) Texturas de una ciudad. Hábitat y Sociedad, 2016, n. ${ }^{\circ}$ 9, pp. 203-208.

$<$ www.habitatysociedad.us.es $>$

http://dx.doi.org/10.12795/HabitatySociedad.2016.i9.11

$\bigcirc$ 